$\xi=-1$

\title{
Preliminary Study for Customer's Online Shopping Satisfaction from Security Perspective
}

\author{
Najma Imtiaz Ali ${ }^{12}$, Suhaila Samsuri ${ }^{1}$, Muhamad Sadry Abu Seman ${ }^{1}$, Imtiaz Ali Brohi ${ }^{1}$, Asadullah Shah ${ }^{1}$ \\ ${ }^{1}$ Kulliyyah of Information and Communication Technology, International Islamic university Malaysia \\ ${ }^{2}$ Institute of Mathematics and Computer Science, University of Sindh, Jamshoro, Pakistan \\ *Corresponding author E-mail: asadullah@iium.edu.my
}

\begin{abstract}
The objective of this paper is to present the results of preliminary study that has been performed to measure the reliability of the questionnaire for collecting the quantitative data for the proposed security model of online shopping satisfaction. This paper is endeavours of our previous paper, in which we have developed the research model. Quantitative methodology was adopted to conduct the study by collecting the data through survey questionnaire based on five point Likert scale. Statistical Package for the Social Sciences (SPSS) version 23.0 was used to analyse the data. Results shows that the Cronbach's alpha value to ensure the reliability of the items is $\geq 0.7$, It means all our variables are acceptable for the further studies and for the actual data collection. This paper conclude that the pilot study is necessary phase to conduct before going to collect the actual data in order to avoid any ambiguity in items. Although the sample data is small for the pilot study still, it shows the strength between the related items.
\end{abstract}

Keywords: Online shopping; security; pilot study Malaysia; Customer satisfaction.

\section{Introduction}

The online shopping has gain huge popularity in the previous years, it has many benefits including the time saving, availability, easy to interact and so on. Despite of this, online shopping also has many risks including security. Online shopping is the major subsidy of technology. Now a day it has gained a lot of popularity among the people. There are many benefits including easily available, time saving, no hassle to park the car. The rapid increasing benefits and availability of internet to everywhere makes online shopping easier for the customer [1]. When we talk about the online shopping, the main issue that one can be faced is security, either it is financial security, personal data security or privacy, system security, security from cybercrime. Trust always play the major role in the field of any activity that involves the exchange of money on internet and customer satisfaction can be achieved if there is trust [2]. After going through the extensive literature review, the security model for online shopping satisfaction was developed in this study[2]. This paper is continuation of previous paper, in which we have performed the extensive literature review to propose the framework for online shopping satisfaction. The research model that we had presented was based on six factors namely financial security, privacy, system security, cybercrime, trust and customer satisfaction, In this paper, the authors presented the results of the preliminary study to show the effect of independent variables financial security, privacy, system security, cybercrime on mediator trust and dependent variable online shopping customer satisfaction.

\section{Background}

This paper is based on the proposed research model for online shopping satisfaction as shown in figure 1 .

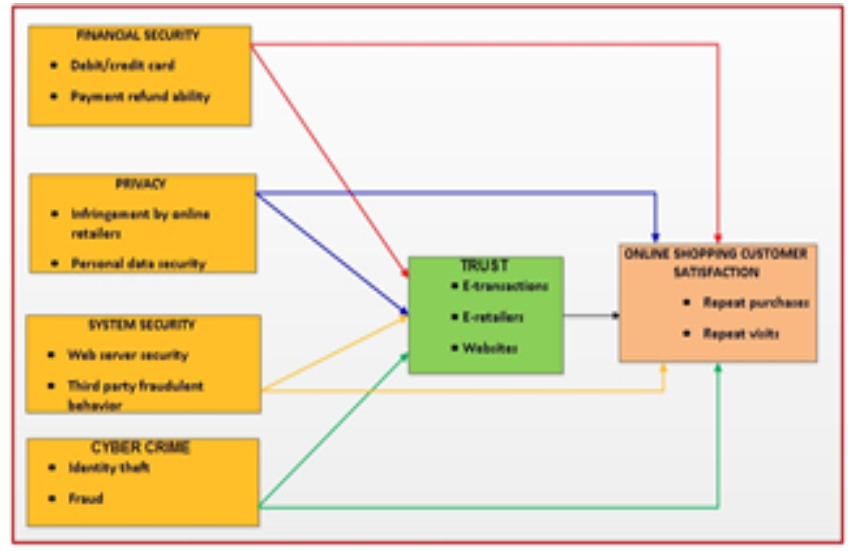

Fig. 1: Proposed Initial Concept Model

The context of this study is Malaysia. As Malaysia is considered as the hub of foreigner. Malaysia has approximately 22 million active internet users (68 percent of the population). Although Malaysian do the online shopping but when it comes to the security, they are very reluctant [2]. Therefore the focus of this research is mainly on the security factors affecting customer's satisfaction during the online shopping. Online shopping is not the new word for the shopping world. With the emergence of internet, it has gained the popularity, especially back in the last two decades. 
There are various factors considered as essential for getting the online shopping satisfaction among the customer. Because it has been considered, the online shopping cannot gain the popularity without the achievement of customer satiation [3]-[7]. Security is the main hurdles faced by the customer during the online shopping The security of financial data also considered as the main reason which effect the customer trust [8], [9]. The debit/ credit security and the payment refundability security is the main hurdles I terms of financial security [10][11].

Another type of security that was also found to be very important in order to gain the customer satisfaction was the privacy [6]. Privacy means the personal data security, as no body wants to share their personal date with third party. Privacy always have the positive impact towards the online shopping trust [12][13]. Ssytem security is the third type of security considered as important in order to gain the customer satisfaction [8], [9].

The fear of third party fradualanat behaviour was found to be the main factor considered in system security [14]. Another factor that was found important was the webserver security [13]. The fourth factor that affects the customer satisfaction and trust was cybercrime [13]. Cybercrime are the crimes that can be performed with the involvement of computer or uses the computer as tool for the electronic crime [15]. The main issues that were related to the cybercrime was fraud and identity theft [16]. The important factor that affect the customer satisfaction was the trust. In this study trust acts as the mediator between the independent variables and the dependent variables [2]. The trust is the prominent factor between the customer and their satisfaction, the business should mountain this relation with full sincerity because no business will be grown up without the achievement of customer trust [17].

\section{Methodology}

The pre-testing and pilot study method was used in this paper, in order to validate the questionnaire and to check the reliability of the questionnaire. In this paper authors also elaborated the process of survey instrument designing and questionnaire pre-testing. Pre-testing of the questionnaire and conducting a pilot study is very essential [18], [19]. Before going to conduct the actual study or data collection, it is better to carry out both these activities. Pretesting is useful for validating the main instrument to be used and to make sure that the final instrument is free of error and any complication. On one hand Pre-testing of the questionnaire is useful exercise because the researcher will learn mistakes and correct them before going out for the real survey. On other hand pilot study is very good practice to check the reliability of the items. Reliability is considered as essential part of validity. Both reliability and validity are interrelated to each other. Therefore the validity of the questionnaire cannot be proven without reliability [20]. Both pilot study and pre-testing of questionnaire suffice with small respondents. This does not take too much time and costs. Therefore one questionnaire pre-test and one pilot study could be conducted in order to get the validity of instruments and relevance of its items to be asked in the questionnaire. In this paper the authors have elaborate the results of pilot study.

\section{Survey Instrument Design}

The proposed variables were measured using multiple items, and the five-point Likert scales. The ranges of choice were from strongly disagree (1) to strongly agree (5). Wherever possible, initial scale items were taken from previously validated measures in e-satisfaction, online shopping customer satisfaction and trust, security, literature and then reorganized and adopted for the current context. The questionnaire was divided into two sections, section A is consist on 10 questions ,related to demographic information of the respondent along with the habits of customer related to the usage to internet and online shopping. The section B was consist of questions related to the proposed dependent, independent and mediator. It has total 59 questions that need to be answered by the respondent. These questions were based on financial security, privacy, system security, cybercrime, trust and online shopping satisfaction. Financial security was evaluated from two dimensions namely Credit/Debit card security and payment refundability. The items for these variables were adopted from different studies [21], [6], [22], [23] . Privacy was evaluated from two aspects i.e. infringement by online retailers and personal data security. The items for these variables were adopted from [21][23]. The system security was also evaluated on two aspects similar to the items stressed by several researchers [6], [23], [24].For cybercrime, two aspects were evaluated i.e. fraud and identity theft. These items for these variables were adopted from the [13] Above all, trust and customer satisfaction are the two most outstanding issues in online shopping [21], [22], [25]. Trust was evaluated from three aspects as adapted from the [21], [25]. Seven other items which were based on literature and the proposed model were also included to evaluate the trust. As far as customer satisfaction is concerned, two indicators were evaluated. They were repeat visits and repeat purchases, the items for these variables were adopted from [21], [22], [26].

\section{Questionnaire Pre-Testing}

Instrument pre-testing is the initial assessment of the survey questionnaire, with a group of random respondents, in order to detect inadequacies of the contents of the questionnaire. For example checking the spellings, layout, and to understand whether the respondents can easily understand the wordings of the questions or whether the questions are biased and ambiguous [19] . Bainas and Chansaker in 2002 stated that the pre-testing is very important as it has significant effects on the overall performance of the instrument like the questionnaire [27] An instrument cannot be valid unless it is reliable. However, the reliability of an instrument does not depend on its validity.

In order to avoid any ambiguity and to rectify the measurement problem, the questionnaire was carefully investigated. The questionnaire was distributed between three different groups. 1) Respondents with online shopping background, 2) Ordinary people and 3) the researcher as suggested by [28]. For this research 50 questionnaires were distributed initially in person to 6 researchers, one from International Islamic University Malaysia (IIUM), one researcher from University of Malaya, one from University utara Malaysia, one from Uni Kuala lumpur, one from taylor's university, one from Open university Malaysia. Remaining 44 questionnaire were distributed to lecturers, an administrator staffs, postgraduate students and undergraduate students of different faculties in IIUM. Out of 44 questionnaires, 35(80 \%) questionnaire were received. All the 6 researcher give their feedback on the questionnaire. This is a very good response rate. The reason to select respondents of the different background is primarily to find out whether they understand the wordings and terminologies used in the questionnaire. In addition, the questionnaire asked the respondents about feedback and comments for further improvement. Consequently, the questionnaire pre-testing was very successful and very good feedback were received from the 41 respondents. Some comments were also received from potential respondents regarding the questionnaire. One $\mathrm{PhD}$ student commented that certain items in the questionnaire seemed repetitive and ambiguous while some suggested changing the layout. One lecturer suggested that the reverse coding questions wordings should be changed somehow to avoid confusion. Another student suggested, that the sequence and wordings of certain items need to be streamlined appropriately. Overall, the feedback received was very interesting and served as important guides for the revision of the final questionnaire. Some items were deleted and some new ones were added, wordings and sequence of the questionnaire were also modified accordingly. After refining the questionnaire, it was ready to collect the preliminary data. 


\section{Pilot Study}

A pilot study was conducted, to check the validity of the items and instrument used. The duration of this pilot study was 6 weeks i.e. from 22 January 2017 to 28 February 2017. The Questionnaire was designed to collect data from the campus communities of five different universities in Klang valley comprising of IIUM, UM, UTM, UKM and UPM. The questionnaire was prepared and distribute through Google form, as internet interaction with the targeted respondents could be done easily. A total of 45 questionnaires were distributed through emails and through Facebook groups of which a total 35 respondents filled up the questionnaire This response rate is $77.7 \%$. In the next section, the descriptive analysis of the data collected from the 35 responses will be explained. This analysis is done by using the SPSS statistical software 23.0 versions.

\subsection{Respondents' profile of the pilot study}

This section describes the profile of the respondents for the pilot study. Table 1. Present the age, gender, monthly income (in Ringgit), University, occupation and ethnicity.

Table 1: Respondents profile

\begin{tabular}{|c|c|c|c|}
\hline Variable & Category & Frequency & $\%$ \\
\hline \multirow[t]{5}{*}{ Age } & $=<20$ & 3 & 8.6 \\
\hline & 21 to 30 & 7 & 20 \\
\hline & 31 to 40 & 22 & 62.9 \\
\hline & 41 to 50 & 3 & 8.6 \\
\hline & $\Rightarrow>50$ & 0 & 0 \\
\hline \multirow[t]{2}{*}{ Gender } & Male & 18 & 51.4 \\
\hline & Female & 17 & 48.6 \\
\hline \multirow[t]{5}{*}{ Income (in Ringgit) } & $=<1000$ & 6 & 17.1 \\
\hline & 1000 to 300 & 11 & 31.4 \\
\hline & 3000 to 5000 & 6 & 17.1 \\
\hline & 5000 to 7000 & 9 & 25.7 \\
\hline & $=>8000$ & 3 & 8.5 \\
\hline \multirow[t]{5}{*}{ University } & IIUM & 12 & 34.3 \\
\hline & UTM S & 5 & 14.3 \\
\hline & UPM & 8 & 22.9 \\
\hline & UKM & 4 & 11.5 \\
\hline & UM & 6 & 17.1 \\
\hline \multirow[t]{4}{*}{ Occupation } & UG students & 6 & 17.1 \\
\hline & PG students & 18 & 51.4 \\
\hline & Administrative staff & 4 & 11.4 \\
\hline & Lecturers & 7 & 20 \\
\hline \multirow[t]{4}{*}{ Ethnicity } & Malay & 15 & 42.9 \\
\hline & Chinese & 4 & 11.4 \\
\hline & Indian & 3 & 18.6 \\
\hline & Others & 13 & 37.1 \\
\hline
\end{tabular}

The respondent profile in this pilot study shows that among the 35 respondents, male $(n=18,51.4 \%)$ and female $(n=17,48.6 \%)$. In terms of age, majority $(\mathrm{n}=22,62.9 \%)$, of them are $31-40$ years old while those whose age are 21 to $30(n=7,20 \%)$; for those in the youngest age of less than 20 years old and ages between 41 to 50 $(\mathrm{n}=3,8.6 \%)$ and none above 50 years old. Age is a significant indicator because generally, the younger age groups are computer literate and not those above 50 years old. On income, the finding of this pilot study shows that income of the respondents majority fall within the range of RM1000 to RM3000 (n=11, 31.4\%). The second higher range was between RM5000 to RM7000 income $(\mathrm{n}=9,25.7 \%)$, the income $=<\mathrm{RM} 1000$ and RM3000 to RM5000 brackets are equally spread respectively $(n=6,17.1 \%)$ and very few are in the $=>$ RM8000 income $(n=3,8.5 \%)$. In terms of university responses, it was found that the highest response $(n=12$, $34.3 \%)$ came from IIUM, second from UPM $(n=8,22.9 \%)$ then from $\mathrm{UM}(\mathrm{n}=6,17.1 \%)$, and the lowest response rate were from UTM $(n=5,14.3 \%)$ and UKM $(n=4,11.5 \%)$. For occupation most of the respondents were postgraduate students $(n=18,51.1 \%)$, then lecturers $(n=7,20 \%)$, undergraduate students $(n=6,17.1 \%)$ and the lowest response came from administrator staff $(n=4,11.4 \%)$.

For ethnicity the highest response was from Malay/ Bumiputera ethnicity $(n=15,42.9 \%)$, then from foreigners $(n=13,37.1)$ Indian ethnicity $(n=3,18.6 \%)$, and lastly from Chinese ethnicity $(n=4$, $11.4 \%)$.

On habit for using internet and online shopping, their responses are as shown in the Table 2.

Table 2: Internet and online shopping habits

\begin{tabular}{|c|c|c|}
\hline \multicolumn{3}{|c|}{ Do you spend time on using internet? } \\
\hline Category & Frequency & Percent \\
\hline Yes & 35 & 100 \\
\hline No & 0 & 0 \\
\hline \multicolumn{3}{|c|}{ How long have you been using the internet? (In years) } \\
\hline Category & Frequency & Percent \\
\hline$=<1$ & 0 & 0 \\
\hline 1 to 3 & 3 & 8.6 \\
\hline 3 to 5 & 3 & 8.6 \\
\hline 5 to 7 & 8 & 22.8 \\
\hline$\Rightarrow 8$ & 21 & 60 \\
\hline Total & 35 & 100 \\
\hline \multicolumn{3}{|c|}{ Have you ever shopped online? } \\
\hline Category & Frequency & Percent \\
\hline No & 1 & 2.9 \\
\hline Yes & 34 & 97.1 \\
\hline Total & 35 & 100 \\
\hline \multicolumn{3}{|c|}{ How often do you shop online? } \\
\hline Category & Frequency & Percent \\
\hline Weekly & 23 & 63.9 \\
\hline Monthly & 5 & 14.3 \\
\hline Quaterly & 23 & 65.7 \\
\hline Yearly & 6 & 17.1 \\
\hline Never & 1 & 2.9 \\
\hline Total & 35 & 100 \\
\hline
\end{tabular}

There was a $100 \%$ internet usage by all the respondents. However, on duration of internet use in terms of years, the longest was $=>8$ years, $(n=21,60 \%)$, after that 5 to 7 years $(n=8,22.9 \%)$ and there are those who have been using the internet only between 3 to 5 and 1 to 3 years $(n=3,8.6 \%)$ for both categories. In response to the question of online shopping, the majority $(n=34,97.1 \%)$ said Yes, and $(\mathrm{n}=1,2.9 \%)$ said No. When asked on how often they shop online $(n=23,65.7 \%)$ shop frequently, $(n=23,65.7 \%)$ shop quarterly, $(n=6,17.1 \%)$ do their online shopping yearly, $(n=5$, $14.3 \%)$ monthly while $(n=1,2.9 \%)$ never shop online.

Finally, it can be said that the $75 \%$ percent response rate achieved in this pilot study was very good and very encouraging for the researcher to proceed. In addition, the sample size was manageable for meaningful analysis. The same result for internet habits and shopping online can be seen in figure 1 .

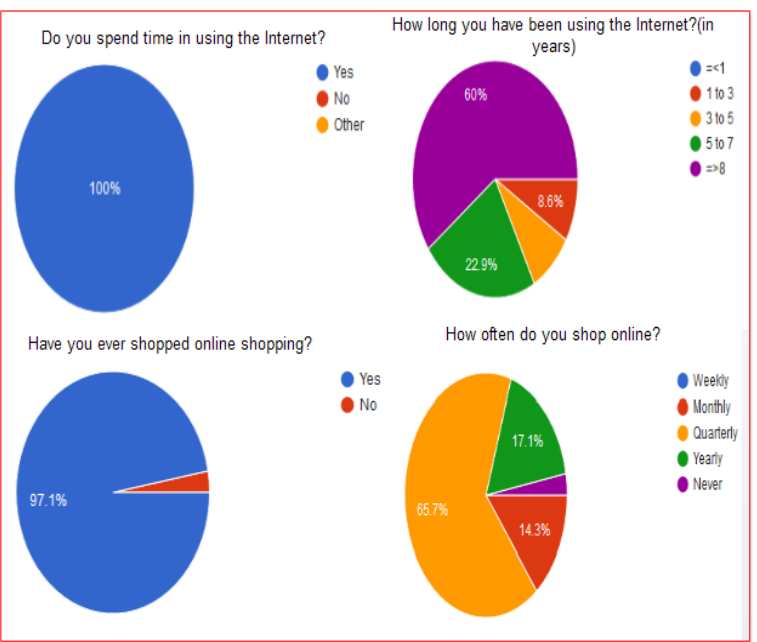

Fig. 2: Internet and shopping Habits 


\section{Instrument Reliability Test}

Cronbach alpha is the test of consistency of items to see how closely related the items are in one group. If the value of Cronbach's alpha or reliability coefficient is 0.7 or above then this is considered as acceptable as stated by Nunally, in 1978.

Sekaran in 2000 also describe that if the value of Cronbach's alpha reliability is less than 0.6 , they are considered as poor, 0.7 or above is considered as acceptable, but if it is 0.8 it is considered as preferable [19] . According to Julie Pallant (2011) if overall results shows that the Cronbach's alpha falls less than 0.7 , then it is considered as poor [30]. In this situation, one has to check the interconnectedness and the score items, and maybe one has to remove the items with less low item-total correlation. Table 3 and Table 4 give the detail about all the Cronbach's Alpha coefficients of the pilot study.

\begin{tabular}{|c|c|c|c|}
\multicolumn{4}{c|}{ Table 3: Case Processing Summary } \\
\hline \multirow{3}{*}{ Cases } & & No. & $\%$ \\
\cline { 2 - 4 } & Valid & 35 & 100.0 \\
\cline { 2 - 4 } & Excluded & 0 & 0 \\
\cline { 2 - 4 } & Total & 35 & 100.0 \\
\hline
\end{tabular}

Table 4: Overall reliability statistics

\begin{tabular}{|c|c|c|}
\hline $\begin{array}{c}\text { Cronbach's } \\
\text { Alpha }\end{array}$ & $\begin{array}{c}\text { Cronbach's Alpha based on standard- } \\
\text { ised item }\end{array}$ & $\begin{array}{c}\text { No. of } \\
\text { items }\end{array}$ \\
\hline .952 & .958 & 59 \\
\hline
\end{tabular}

The individual Cronbach's alpha value of proposed variables can be shown in table 5. All the values comes into the range of 0.7 to 1.00. Kat Mirian sated in 2004 that "absolute value of 0.7 (or sometimes 0.8 or 0.6 ) is normally taken as the criterion of acceptability" [2].

Table 5: Overall Reliability

\begin{tabular}{|c|c|c|c|}
\hline Construct & $\begin{array}{l}\text { No. of } \\
\text { items }\end{array}$ & $\begin{array}{l}\text { Cronbach's } \\
\text { Alpha }\end{array}$ & Result \\
\hline $\begin{array}{l}\text { Online Shopping cus- } \\
\text { tomer satisfaction } \\
\text { (OSCS) }\end{array}$ & 11 & .832 & Preferable \\
\hline Trust (TR) & 18 & .966 & Preferable \\
\hline Financial Security(FS) & 7 & .732 & Acceptable \\
\hline Privacy(PR) & 9 & .731 & Acceptable \\
\hline System Security(SS) & 8 & .915 & Preferable \\
\hline CyberCrime (CC) & 6 & .960 & Preferable \\
\hline
\end{tabular}

Table 6 shows the correlation among the variables. Financial Security FS has significant relation with Satisfaction $r$ $(35)=.347$. System Security SS have strong relation with the trust $\mathrm{r}(35)=.664$ and satisfaction i.e $\mathrm{r}(35)=.769$ along with strong relation with privacy $\mathrm{r}(35)=.508$. Privacy have significant strong relation with System security SS r(35) = along with trust $\mathrm{r}(35)=.615$ and satisfaction $\mathrm{r}(35)=.566$. Cybercrime also significant negative relation with trust $\mathrm{r}(35)=-.397$ and satisfaction $\mathrm{r}(35)=.407$. Trust have strong elation with satisfaction $\mathrm{r}(35)=.827$. This shows that there is good correlation among the variables [30-32]

\begin{tabular}{|c|c|c|c|c|c|c|}
\hline & FS & SS & PR & $\mathrm{CC}$ & TR & SAT \\
\hline FS & 1 & & & & & \\
\hline SS & .313 & 1 & & & & \\
\hline PR & .266 & $.508^{* *}$ & 1 & & & \\
\hline $\mathrm{CC}$ & .057 & .084 & .244 & 1 & & \\
\hline TR & .321 & $.664 * *$ & $.615 * *$ & $-.397 *$ & 1 & \\
\hline SAT & $.347 *$ & $.769 * *$ & $.566 * *$ & $-.407 * *$ & $.827 * *$ & 1 \\
\hline
\end{tabular}

$*$. Correlation is significant at the 0.05 level (2-tailed).

**. Correlation is significant at the 0.01 level (2-tailed).
$\mathrm{FS}=$ Financial security, $\mathrm{SS}=$ system security, $\mathrm{PR}=$ privacy, $\mathrm{CC}=\mathrm{Cyber}-$ crime, TR Trust, SAT $=$ Satisfaction.

\section{Discussion}

Trust and Online shopping satisfaction remain the main issue during the online shopping. This study was carried out to know the main security issues faced by the People in Malaysia during the online shopping. Financial security, privacy, system security and cybercrime were the main security issues, which effects the trust and the online shopping satisfaction. The security model for online shopping was developed after going through the literature review and the expert interviews.

\section{Conclusion}

In this paper authors presented the pilot study that was conducted to ensure the validity of the questionnaire and to have some idea about the items means, reliability and correlation. Now the researcher can move further to collect the actual data for the study. From results it has been observed that the conbach's alpha value for all the constructs was above the 0.7 which is the acceptable to ensure the relation between the items used in the questionnaire. Also the inter correlation of the items is strong.

\section{References}

[1] M. . Akroush and M. M. Al-Debei, "An Integrated Model of Factors Affecting Consumer Attitudes Towards Online Shopping," Bus. Process Manag. J., vol. 21, no. 6, pp. 1353-1376, 2015.

[2] N. I. Ali, S. Samsuri, M. Sadry, I. A. Brohi, and A. Shah, "Online Shopping Satisfaction in Malaysia: A Framework for Security, Trust and Cybercrime," in 2016 6th International Conference on Information and Communication Technology for The Muslim World (ICT4M), 2016, pp. 194-198.

[3] H. Momtaz, A. Karim, M. A. Islam, and K. H. Ku Ariffin, "Customers Satisfaction on Online Shopping in Malaysia," Int. J. Bus. Manag., vol. 6, no. 10, pp. 1-9, 2011.

[4] U. Tandon, R. Kiran, and A. Sah, "Analyzing customer satisfaction: users perspective towards online shopping," Nankai Bus. Rev. Int., vol. 8, no. 3, pp. 266-288, 2017.

[5] A. D. Athanassopoulos, S. Gounaris, and V. Stathakopoulos, "Behavioural responses to customer satisfaction: an empirical study," Eur. J. Mark., vol. 35, no. 5/6, pp. 687-707, 2001.

[6] X. Liu, M. He, F. Gao, and P. Xie, "An empirical study of online shopping customer satisfaction in China: a holistic perspective," Int J. Retail Distrib. Manag., vol. 36, no. 11, pp. 919-940, 2008.

[7] "DETERMINANTS OF E-COMMERCE CUSTOMER SATISFACTION , TRUST , AND," p. 2007, 2007.

[8] D. M. Szymanski and R. T. Hise, "E-satisfaction: an initial examination,” J. Retail., vol. 76, no. 3, pp. 309-322, 2000.

[9] H. Evanschitzky, G. R. Iyer, J. Hesse, and D. Ahlert, "Esatisfaction: A re-examination," J. Retail., vol. 80 , no. 3, pp. 239247, 2004

[10] L. H. Wei, M. A. Osman, N. Zakaria, and T. Bo, "Adoption of ecommerce online shopping in Malaysia," Proc. - IEEE Int. Conf. Ebus. Eng. ICEBE 2010, pp. 140-143, 2010.

[11] J. Langsner, B. A. D. Miyazaki, and A. Fernandez, "Consumer Perceptions of Privacy and Security Risks for Online Shopping," Management, vol. 35, no. 1, pp. 1-7, 2006.

[12] F. Belanger, J. S. Hiller, and W. J. Smith, "Trustworthiness in Electronic Commerce: The Role of Privacy, Security, and Site Attributes,” J. Strateg. Inf. Syst., vol. 11, pp. 245-270, 2002.

[13] S. Pittayachawan, "Fostering consumer trust and purchase intention in B2C e-commerce," Bus. Inf. Technol., no. August, 2007.

[14] A. D. Miyazaki and A. Fernandez, "Internet Privacy and Security: An Examination of Online Retailer Disclosures," J. Public Policy Mark., vol. 19, no. 1, pp. 54-61, 2000.

[15] P. Aggarwal, "Review on cyber crime and security," Int. J. Res. Eng. Appl. Sci., vol. 2, no. 1, pp. 48-51, 2014. 
[16] S. Pittayachawan, "Fostering consumer trust and purchase intention in B2C e-commerce," Bus. Inf. Technol., no. August, 2007.

[17] M. J. Kim, N. Chung, and C. K. Lee, "The effect of perceived trust on electronic commerce: Shopping online for tourism products and services in South Korea," Tour. Manag., vol. 32, no. 2, pp. 256-265, 2011.

[18] S. H. Channar, A. A. S. Mehran, N. I. Ali, and I. A. Brohi, “Assesment of problems faced by female post graduate students: A case study of Jamshoro city universities," 2017 4th IEEE Int. Conf. Eng. Technol. Appl. Sci., no. November, pp. 1-4, 2017.

[19] B. Sekaran, U., Research Methods for Business: A Skill Building Approach. 2009.

[20] J. C. Nunnally, Psychometric theory, 2nd Editio. McGraw-Hill, New York., 1978.

[21] M. Wolfinbarger and M. C. Gilly, "eTailQ: dimensionalizing , measuring and predicting etail quality," vol. 79, pp. 183-198, 2003.

[22] C.-M. Chiu, C.-C. Chang, H.-L. Cheng, and Y.-H. Fang, "Determinants of customer repurchase intention in online shopping," Online Inf. Rev., vol. 33, no. 4, pp. 761-784, 2009.

[23] C.-H. Park and Y.-G. Kim, "Identifying key factors affecting consumer purchase behavior in an online shopping context," Int. J. Retail Distrib. Manag., vol. 31, no. 1, pp. 16-29, 2003.

[24] M. Vinhal, M. Laroche, and M. Richard, "Journal of Retailing and Consumer Services How to reduce perceived risk when buying online: The interactions between intangibility, product knowledge brand familiarity, privacy and security concerns," J. Retail. Consum. Serv., vol. 21, no. 4, pp. 619-629, 2014.

[25] D. Gefen, E. Karahanna, and D. W. Straub, "Trust and TAM in online shopping: An integrated model," 2003.

[26] R. E. Anderson and S. S. Srinivasan, "E-Satisfaction and ELoyalty: A Contingency Framework E-Loyalty: A Contingency Framework," no. January, 2014.

[27] B. and Chansarkar, Introducing Marketing Research England: John Wiley \& Sons, Ltd. 2002.

[28] A. B. A. S. Dr. Husnain Iqbal, Proceeding of Icarbss 2017: VOLUME 1 3rd International Conference on Advanced Research in Business and Social Sciences 2017. 2017.

[29] Kate Miriam Loewenthal, An Introduction to Psychological Tests and Scales - Kate Miriam Loewenthal - Google Books. 2004.

[30] Pallant, J. SPSS survival manual; A step by step guide to data analysis using SPSS for windows (3rd ed.). (2007).

[31] Ahmed, S. F. (2007, December). A new approach in Industrial automation application" Embedded system design for Injection Molding Machine". In Multitopic Conference, 2007. INMIC 2007. IEEE International (pp. 1-5). IEEE

[32] Ahmed, S. F., Desa, H., Azim, F., Surti, A., \& Hussain, W. (2013, April). Remote access of SCADA with online video streaming. In Computer Science \& Education (ICCSE), 2013 8th International Conference on (pp. 270-274). IEEE. 